\title{
Cerebrospinal fluid examination may be useful in diagnosing neurosyphilis in asymptomatic HIV+ patients with syphilis
}

\author{
El examen del líquido céfalo raquídeo puede ser útil en el diagnóstico de neurosífilis en \\ pacientes VIH + asintomáticos con sífilis \\ Ronald Salamano1, Raquel Ballesté2, Abayubá Perna1, Natalia Rodriguez², Diego Lombardo', Natalia \\ García 2 Pablo López², Pablo Cappuccio ${ }^{3}$
}

\begin{abstract}
Lumbar puncture in neurologically asymptomatic HIV+ patients is still under debate. There are different criteria for detecting neurosyphilis through cerebrospinal fluid (CSF), especially in cases that are negative through the Venereal Disease Research Laboratory (VDRL), regarding cellularity and protein content. However, a diagnosis of neurosyphilis can still exist despite negative VDRL. Treponema pallidum hemagglutination assay (TPHA) titers and application of the TPHA index in albumin and IgG improve the sensitivity, with a high degree of specificity. Thirty-two patients were selected for this study. VDRL was positive in five of them. The number of diagnoses reached 14 when the other techniques were added. It was not determined whether cellularity and increased protein levels were auxiliary tools in the diagnosis. According to our investigation, CSF analysis using the abovementioned techniques may be useful in diagnosing neurosyphilis in these patients.
\end{abstract}

Keywords: neurosyphilis, HIV positive, VDRL, TPHA in CSF, TPHA indexes.

\section{RESUMO}

La punción lumbar (PL) en pacientes VIH+ neurológicamente asintomáticos es controversial. Existen diferentes criterios para detectar en el líquido cefalorraquídeo (LCR) neurosífilis (NS): el examen Venereal Disease Research Laboratory (VDRL) en primer lugar, en caso de negatividad: la celularidad y el tenor de proteinas. Sin embargo el diagnóstico de NS puede ser sostenido a pesar de la negatividad de las técnicas mencionadas. La titulación del Treponema pallidum hemagglutination assay (TPHA) y la aplicación del índice de TPHA en Albúmina e lg G mejoran la sensibilidad asociando elevado grado de especificidad. 32 pacientes fueron seleccionados para este estudio, el VDRL fue positivo en 5. El diagnóstico se elevó a 14 cuando se sumaron el resto de las técnicas. No se evidenció que la celularidad y el aumento de proteínas fueran herramientas auxiliares para el diagnóstico. De acuerdo a nuestro trabajo el estudio del LCR con las técnicas señaladas puede ser de utilidad en el diagnóstico de NS en estos pacientes.

Palavras-chave: neurosífilis, VIH positivo, VDRL, TPHA en LCR, indices en TPHA

Whether lumbar puncture should be indicated for diagnosing neurosyphilis in patients who are coinfected with the human immunodeficiency virus (HIV) and Treponema pallidum (T. pallidum) but do not have any symptoms or neurological signs is a matter for discussion ${ }^{1,2}$.

The European guidelines recommend lumbar puncture in cases of symptomatic patients (neurological, ophthalmological or otological symptoms) and asymptomatic HIV-positive patients with Venereal Disease Research Laboratory (VDRL) test results greater than or equal to $1 / 32$ in serum and CD4 less than or equal to 350. These guidelines suggest that lumbar puncture should not be compulsory but that it could be indicated in cases of late latent syphilis or syphilis of undetermined duration ${ }^{3}$.

In 2002, the Centers for Disease Control and Prevention (CDC) recommended lumbar puncture for patients with late latent syphilis or syphilis of undetermined duration. This recommendation was later revised to include reactive VDRL $\geq 1 / 32$ in serum and CD4 cell counts $\leq 350$ cells $/ \mathrm{ml}$. Since 2010, CDC has not been recommending lumbar puncture for asymptomatic patients.

\footnotetext{
${ }^{1}$ Hospital de Clínicas, Instituto de Neurología, Sección Neuroinfectología, Cátedra de Neurología, Montevideo, Uruguay;

${ }^{2}$ Hospital de Clínicas, Departamento de Laboratorio Clínico, Sección Inmunología, Montevideo, Uruguay;

${ }^{3}$ Hospital Pasteur, Servicio de Enfermedades Infecto-Contagiosas (SEIC), Montevideo, Uruguay.

Correspondence: Ronald Salamano; José E. Rodó 1714/301; Montevideo, Uruguay; E-mail: rsalamano@hotmail.com

Conflict of interest: There is no conflict of interest to declare.

Received 08 July 2015; Received in final form 13 October 2015; Accepted 03 November 2015.
} 
VDRL is still the fundamental tool for diagnosing neurosyphilis. Its moderate sensitivity (30-70\%) in immunocompetent patients ${ }^{4}$ and its significantly decreased sensitivity in patients who are immunosuppressed due to HIV, makes it necessary to use other techniques for diagnosing this condition. These may include cellularity and CSF protein levels, in those cases that cannot be detected through VDRL ${ }^{5,6,7}$.

High cellularity and CSF protein levels are indicative criteria of neurosyphilis in the absence of other diseases. Unfortunately, these parameters are of little use in cases of coinfection with HIV. It has been accepted that in cases of HIV-negative patients, presentation of pleocytosis of more than 10 cells and CSF protein levels of more than $0.45 \mathrm{mg} / \mathrm{dl}$ would be indicative of neurosyphilis, while for HIV-positive patients, the parameter of cellularity increases to 20 cells and the protein level is still the same ${ }^{8}$.

The polymerase chain reaction (PCR) shows ambiguous responsiveness with regard to diagnosing neurosyphilis ${ }^{9}$. It is possible that the low T. pallidum count in CSF makes it impossible for this technique to be of use ${ }^{10}$.

The rabbit infectivity test is considered to be the gold standard for making the diagnosis. However, this technique is cumbersome to put into practice and the results can take months ${ }^{11}$.

Other immunological diagnostic alternatives are also applied to CSF, such as the Treponema pallidum hemagglutination assay (TPHA) in CSF and the TPHA-IgG and TPHA-albumin tests. These can also help in this regard, since it occurs in HIV-negative patients with symptoms and signs of neurosyphilis ${ }^{11,12,13}$.

TPHA is an indirect hemagglutination test through which it is possible to assay for anti-T. pallidum specific antibodies in serum and CSF. Its negativity in CSF has a high negative predictive value (as also seen with the FTA-ABS). Random positive TPHA findings in CSF do not always indicate neurosyphilis and they may simply mean that passage of antibodies from the blood is occurring. Thus, TPHA is considered to be a technique with high sensitivity and low specificity. Therefore, authors such as Luger et al. have suggested that the mere presence of high TPHA titers in CSF could be considered to have diagnostic value regarding neurosyphilis.

The TPHA-albumin index correlates the anti-Treponema antibody titer in CSF and serum with the albumin quotient, thus assessing the condition of the blood-brain barrier. On Reibergrams, this can be seen to be connected with intrathecal production of specific antibodies (IgG quotient), which would indicate local activity, while the IgG index itself might have less sensitivity in this regard ${ }^{12,13,14,15,16}$.

These diagnostic alternatives have made it possible to obtain information in cases of symptomatic HIV-negative patients. They are not routinely used for HIV-positive patients.

As mentioned earlier, different authors ${ }^{4}$ have agreed that neurosyphilis in HIV-positive patients can be detected more consistently in those who show at least some of the following criteria: CD4 less than or equal to 350 and RPR or VDRL greater than or equal to $1 / 32$. The 2008 European guidelines accept the possibility that lumbar puncture could be performed in cases of untreated syphilis of unknown duration or that have remained untreated for at least one year, with persistent serological findings despite treatment with penicillin G benzathine ${ }^{3}$.

The aim of this study was to observe the performance of these techniques: not only those such as CSF VDRL for which a broad consensus exists, but also those defined as alternative techniques, including investigation of cellularity and CSF protein levels and immunological techniques (CSF TPHA, TPHA-albumin index and TPHA-IgG index), applied to a population of HIV-positive patients who were coinfected with $T$. pallidum but were asymptomatic from a neurological point of view.

\section{METHOD}

A cross-sectional study was conducted on a series of cases between the years 2004 and 2013.

The criterion for selecting the patients was that they needed to be HIV+ and TPHA+ in blood, but were asymptomatic from a neurological point of view. A lumbar puncture was performed on those patients who fulfilled at least one of the following criteria ${ }^{13}$ :

- $\quad$ RPR or VDRL in blood greater than or equal to 1:32

- CD4 less than or equal to $350 \mathrm{~mm}^{3}$

- Untreated syphilis of unknown duration or of over one year in duration

- RPR or VDRL in blood that was persistent despite treatment with penicillin $\mathrm{G}$ benzathine.

Thirty-two patients were included, among whom 18 (56\%) were male and 14 (44\%) were female.

The criteria for lumbar puncture are shown in Table 1. Three of the patients fulfilled one or more of the inclusion criteria but no data on them were recorded. The average age was 40 years old (standard deviation, SD = 9). Cases with traumatic lumbar puncture were excluded.

Table 1. Indication of lumbar puncture.

\begin{tabular}{lc}
\hline Indication of lumbar puncture & $\mathrm{N}(\%)$ \\
\hline Positive VDRL despite treatment & $10(31.3)$ \\
Syphilis of uncertain beginning & $3(9.4)$ \\
$V D R L \geq 32$ & $7(21.9)$ \\
$V D R L \geq 32$ / positive VDRL despite treatment & $7(21.9)$ \\
$V D R L \geq 32$ / syphilis of uncertain beginning & $2(6.3)$ \\
No data & $3(9.4)$ \\
Total & $32(100)$ \\
\hline VDRL Venereal Disease Research Laboratory
\end{tabular}


Patients were considered to present asymptomatic neurosyphilis if they were VDRL+ in CSF and/or showed TPHA in $\mathrm{CSF} \geq 320$, and/or showed TPHA-albumin index $\geq 70$.

Patients were considered to probably present neurosyphilis if they only showed TPHA-IgG index $\geq 2$.

The formulae applied for the TPHA-albumin and TPHA-IgG indexes were as follows:

- TPHA-albumin index: CSF TPHA titer/albumin quotient $x 103$

Ref. value $\geq 70$

- Albumin quotient: CSF albumin (mg/dl)/serum albumin (mg/dl)

Ref. value: 0.0018-0.0074

- TPHA IgG index: CSF TPHA titer $x$ total serum IgG/serum TPHA titer $\mathrm{x}$ total IgG CSF

Ref. value: $\geq 2$

The variables analyzed were as follows: serum VDRL, CSF VDRL, CSF TPHA, TPHA-albumin index, TPHA-IgG index, cellularity, CSF protein and glucose levels, AIDS stage, combined anti-retroviral treatment (ART) and CD4 at the time of the lumbar puncture.

The Reibergram was not taken into account given that the variability of the data obtained might have been a consequence of the coinfection. Positive values were not exclusively due to anti-T. pallidum antibodies that were synthesized intrathecally. Moreover, negative values would not rule it out within the context of immunosuppression.

For analysis purposes, the sample was first considered according to CSF VDRL positivity and then according to TPHA positivity in both groups (positive and negative CSF VDRL).

The sample was then analyzed after excluding the CSF VDRL-positive patients, and the performance of CSF TPHA and TPHA-albumin and IgG index assaying was observed in these patients.

The numbers of cells and protein levels in the patients diagnosed with neurosyphilis according to the criteria defined in this study were compared with the levels in patients that did not have this a diagnosis. The same variables were then compared between the patients who had been diagnosed as presenting neurosyphilis exclusively through the VDRL test, versus those who were CSF VDRL-negative.

The data were processed and tabulated using the SPSS software, version 17.0. To describe the population, the mean was used for the continuous variables, with the corresponding standard deviations, and proportions for the categorical variables.

In comparisons between continuous variables, the Student t-test and the Mann-Whitney test were used in accordance with the application conditions, while for the categorical variables, the chi-square test was used to compare proportions.

A significance level of alpha $=0.05$ was used.

To gather the data, a specific protocol was established. The data were obtained from the clinical records of two hospitals (HC and SEIC). Lumbar puncture was indicated in accordance with the current guidelines and purely for the purposes of clinical care. Strict confidentiality was maintained with regard to the identity of the patients included and only the overall data have been disclosed here.

\section{RESULTS}

Fourteen patients (43.8\%) presented one or more tests that were positive for neurosyphilis. Among them, five (15.5\%) were CSF VDRL-positive, while for the remaining nine, the definitive probable diagnosis of neurosyphilis was made through CSF TPHA or the TPHA-albumin and TPHA-IgG indexes, which were greater than or equal to the reference values.

The patients with positive neurosyphilis tests showed titers for serum VDRL between $2 \mathrm{U}$ and $1024 \mathrm{U}$, with an average of $64 \mathrm{U}$. The patients with high titers (above $16 \mathrm{U}$ ) were also reactive in the CSF VDRL test, or had more than two positive tests for neurosyphilis, unlike those with low titers (less than or equal to $16 \mathrm{U}$ ), which only corresponded to TPHA-IgG indexes. In our study, one patient who was VDRL-positive showed $2 \mathrm{U}$ and another showed 16U. Table 2 shows these results.

The patients with diagnoses achieved through CSF with a positive VDRL test were linked in a statistically significant manner to the fact that they were at the AIDS stage (chi-square test; $\mathrm{p}<0.037$ ). This association was not found when the criterion was that patients had to have a positive CSF test. Furthermore, no statistical association was found between ART and a positive VDRL test and the rest of the diagnostic parameters.

Comparison of cellularity and CSF protein levels in patients with neurosyphilis according to the two diagnostic criteria through CSF mentioned earlier showed that there were no significant differences from a statistical point of view (see Tables 3 and 4).

\section{DISCUSSION}

Carrying out a lumbar puncture in HIV-positive patients with positive serological blood tests for syphilis is a matter of controversy in relation to patients who do not show any symptoms and/or neurological or ophthalmological signs ${ }^{1,2}$.

In our study, carrying out a LUMBAR PUNCTURE among patients who were selected in accordance with the criteria laid out above, in the Material and Methods section, seems to have been appropriate, given that this allowed us to detect five patients (15\%) who had positive CSF VDRL tests (which therefore confirmed the diagnosis of neurosyphilis). If we add the criteria set forth by Luger et al. ${ }^{11,12}$, this percentage increases to $43.8 \%$ (14 patients). 
Table 2. Main features of the 14 patients with at least one positive test for neurosyphilis.

\begin{tabular}{|c|c|c|c|c|c|c|c|c|c|c|}
\hline Patient & $\begin{array}{l}\text { VDRL in } \\
\text { blood }\end{array}$ & $\begin{array}{l}\text { Indication of lumbar } \\
\text { puncture }\end{array}$ & $\begin{array}{l}\text { CSF } \\
\text { VDRL }\end{array}$ & $\begin{array}{l}\text { TPHA-albumin } \\
\text { index }\end{array}$ & $\begin{array}{l}\text { TPHA-IgG } \\
\text { index }\end{array}$ & TPHA & $\begin{array}{l}\text { received } \\
\text { ART }\end{array}$ & $\begin{array}{l}\text { At AIDS } \\
\text { stage }\end{array}$ & $\begin{array}{l}\text { GB in } \\
\mathrm{CSF}\end{array}$ & $\begin{array}{l}\text { CSF protein } \\
\text { levels }\end{array}$ \\
\hline 1 & +128 & Cut-off point $\geq 32$ & $+(4 U)$ & 14 & 0.6 & 128 & No & Yes & 2 & 0.60 \\
\hline 2 & +128 & Cut-off point $\geq 32$ & $+(1 \cup)$ & 38 & 0.8 & 256 & No & Yes & 1 & 0.47 \\
\hline 3 & +32 & Cut-off point $\geq 32$ & $+(16 U)$ & 13027 & 69 & 3258 & Yes & No & 13 & 0.30 \\
\hline 4 & +64 & Cut-off point $\geq 32$ & + & 278 & 4.16 & 640 & No data & No data & 0 & 0.25 \\
\hline 5 & +1024 & Cut-off point $\geq 32$ & + & 17 & No data & 64 & Yes & Yes & 2 & 0.24 \\
\hline 6 & +2 & $\begin{array}{c}\text { Syphilis of uncertain } \\
\text { beginning }\end{array}$ & - & 3.4 & 5.3 & 32 & Yes & Yes & 0 & 0.43 \\
\hline 7 & +64 & $\begin{array}{l}\text { Cut-off point } \geq 32 \\
\text { Persistent }+ \text { VDRL }\end{array}$ & - & No data & No data & 640 & Yes & No & 40 & 0.37 \\
\hline 8 & +64 & Cut-off point $\geq 32$ & - & 56 & No data & 512 & Yes & Yes & 0 & 0.50 \\
\hline 9 & +64 & Persistent + VDRL & & 23 & 20.3 & 80 & No & No & 10 & 0.28 \\
\hline 10 & +16 & Persistent + VDRL & - & 23 & 10 & 80 & No & No & 2 & 0.35 \\
\hline 11 & +256 & $\begin{array}{c}\text { Syphilis of uncertain } \\
\text { beginning } \\
\text { Cut-off point } \geq 32\end{array}$ & - & 409 & 4.4 & 1024 & Yes & No & 1 & 0.24 \\
\hline 12 & +64 & $\begin{array}{c}\text { Cut-off point } \geq 32 \\
\text { Syphilis of uncertain } \\
\text { beginning }\end{array}$ & - & 11 & 2.6 & 32 & No & No & 2 & 0.26 \\
\hline 13 & +32 & Cut-off point $\geq 32$ & - & 64 & No data & 512 & Yes & No data & $\begin{array}{l}\text { No } \\
\text { data }\end{array}$ & No data \\
\hline 14 & +64 & Cut-off point $\geq 32$ & - & 113 & 157 & 320 & No data & No data & 0 & 0.25 \\
\hline
\end{tabular}

VDRL: Venereal Disease Research Laboratory.

Table 3. Comparison of the CSF cytochemical data, taking at least one positive CSF test as the diagnostic criterion.

\begin{tabular}{lccc} 
& $\begin{array}{c}\text { Patients with positive neurosyphilis } \\
\text { tests (mean, SD) }\end{array}$ & $\begin{array}{c}\text { Patients with negative neurosyphilis } \\
\text { tests (mean, SD) }\end{array}$ & p-value \\
\hline CSF glucose levels $(\mathrm{mg} / \mathrm{dl})$ & $0.6(0.1)$ & $0.6(0.09)$ & 0.45 \\
CSF protein levels $(\mathrm{mg} / \mathrm{dl})$ & $0.35(0.10)$ & $0.32(0.11)$ & 0.20 \\
White blood cell count $\left(\mathrm{mm}^{3}\right)$ & $5.6(11.1)$ & $1.41(2.7)$ & 0.14 \\
\hline
\end{tabular}

Table 4. Comparison of the CSF cytochemical data, taking a positive CSF VDRL test as the diagnostic criterion.

\begin{tabular}{lccc}
\hline & $\begin{array}{c}\text { Patients with positive neurosyphilis } \\
\text { tests (mean, SD) }\end{array}$ & $\begin{array}{c}\text { Patients with negative neurosyphilis } \\
\text { tests (mean, SD) }\end{array}$ & p-value \\
\hline CSF glucose levels $(\mathrm{mg} / \mathrm{dl})$ & $0.5(0.1)$ & $0.6(0.1)$ & 0.081 \\
CSF protein levels $(\mathrm{mg} / \mathrm{dl})$ & $0.37(0.2)$ & $0.32(0.1)$ & 0.37 \\
White blood cell count $\left(\mathrm{mm}^{3}\right)$ & $3.6(5.3)$ & $3.2(8.1)$ & 0.9 \\
\hline
\end{tabular}

Comparison of the patients with neurosyphilis in accordance with the two criteria used in making the diagnosis through CSF with the negative patients did not lead to any correlation with being administered ART or with being at the AIDS stage, with the exception of positive CSF VDRL tests and the AIDS stage.

This suggests that the TPHA-albumin and IgG indexes in CSF, as well as the total amount of TPHA in CSF, could have diagnostic value at stages unconnected to the AIDS stage. It needs to be pointed out that it is important to include these parameters in making routine diagnoses of neurosyphilis. If we had disregarded them, these patients (who comprised $28.3 \%$ of the diagnosed population) would have remained undiagnosed.

With regard to the correlation with the cytology and CSF protein levels, we did not find any data that would have enabled us to establish whether these parameters of the cytochemical tests were of diagnostic use under these circumstances.

Validation of these diagnostic indicators is undeniably difficult, because the gold standard tests are difficult to carry out in practice and it is especially difficult to assess the analytical performance. However, this highlights the importance of complementary techniques.

The conclusion from our data is that lumbar puncture should be performed in all the patients who comply with the aforementioned selection criteria. The indexes described here should be used through the techniques of Luger et al. in CSF, together with the classical VDRL test. All patients who have had positive results in one or more of these tests should be given appropriate treatment, since these tests are indicative of asymptomatic neurosyphilis. 
1. Ghanem KG, Moore RD, Rompalo AM, Erbelding EJ, Zenilman JM, Gebo KA. Lumbar puncture in HIV infected patients with syphilis and no neurologic symptoms. Clin Infect Dis. 2009;48(6):816-21. doi:10.1086/597096

2. Libois A, De Wit S, Poll B, García F, Florence E, Del Río A et al. HIV and syphilis: when to perform a lumbar puncture. Sex Transm Dis. 2007;34(3):141-4. doi:10.1097/01.olq.0000230481.28936.e5

3. French P, Gomberg M, Janier M, Schmidt B, Voorst Vader P, Young H et al. IUSTI: 2008 European Guidelines on the Managements of Syphilis. Int J STD AIDS. 2009;20(5):300-9. doi:10.1258/ijsa.2008.008510

4. Tramont EC. Treponema pallidum (syphilis). In: Mandell, Douglas and Bennett's Principles and practice of infectious diseases. 5th ed. New York: Elsevier; 2009. p. 2474-90.

5. Hart G. Syphilis tests in diagnostic and therapeutic decision making. Ann Intern Med. 1986;104(3):368-76. doi:10.7326/0003-4819-104-3-368

6. Marra CM, Maxwell CL, Collier AC, Robertson KR, Imrie A. Interpreting cerebrospinal fluid pleocytosis in HIV in the era of potent antiretroviral therapy. BMC Infect Dis. 2007;7:37. doi:10.1186/1471-2334-7-37

7. Marra CM, Maxwell CL, Smith SL, Lukehart SA, Rompalo AM, Eaton $M$ et al. Cerebrospinal fluid abnormalities in patients with syphilis: association with clinical and laboratoryfeatures. J Infect Dis. 2004;189:369-76. doi:10.1086/381227

8. Marra CM. Neurosyphilis in infections of the central nervous system. In: Scheld WM, Whitley RJ, Marra CM, editors. Infections of the central nervous system. 4th ed. Philadelphia: Wolters Kluwer; 2014. p. 659-73.

9. Marra CM, Gary DW, Kuypers J, Jacobson MA. Diagnosis of Neurosyphilis in patients infected with Human Immunodeficiency Virus Type 1. J Infect Dis 1996;174(1):219-21. doi:10.1093/infdis/174.1.219

10. Machado L, Livramento JA, Vianna LS. Cerebrospinal fluid analysis in infectious diseases of the nervous system: when to ask, what to ask, what to expect. Arq Neuropsiquiatr. 2013;71(9B):693-8. doi:10.1590/0004-282X20130153

11. Turner TB, Hardy PH, Newman B. Infectivity tests in syphilis. Br J Vener Dis. 1969;49(3):183-96.

12. Luger AF, Schmidt BL, Steyer K, Schenwald E. Diagnosis of neurosyphilis by examination of the cerebrospinal fluid. Br J Vener Dis. 1981;57(4):232-7.

13. Müller F, Moskophidis M. Estimation of the local production of antibodies for Treponema Pallidum in the Central Nervous System of patients with Neurosyphilis. Br J Vener Dis. 1983;59:80-4.

14. Marra CM. Update on neurosyphilis. Curr Infect Dis Rep. 2009;11:127-34. doi:10.1007/s11908-009-0019-1

15. Ghanem KG, Moore RD, Rompalo AM, Erbelding EJ, Zenilman JM, Gebo KA. Neurosyphilis in a clinical cohort of HIV-1 infected patients. AIDS. 2008;22(10):1145-51. doi:10.1097/QAD.0b013e32830184df

16. Luger AF, Schmidt BL, Kaulich M. Significance of laboratory findings for the diagnosis of neurosyphilis. Int J of STD \& AIDS. 2000;11(4):224-34. doi:10.1258/0956462001915750 